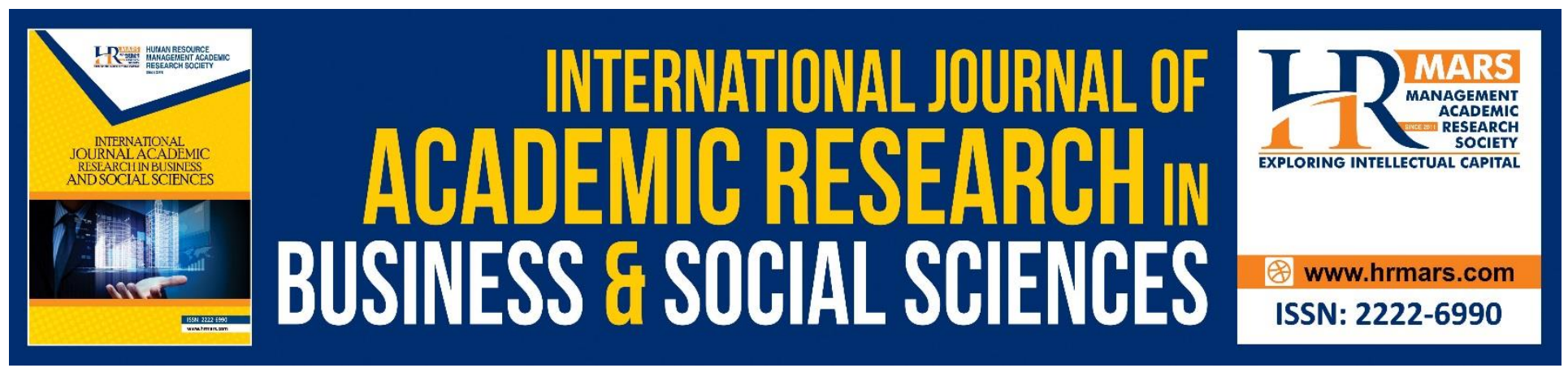

\title{
Characteristics of Effective Assatizah in Higher Religious Institutions (HRIs)
}

\author{
Husnina Yusoff, Ashraff Anuar, Azizan Asmuni, Ismi Arif
}

To Link this Article: http://dx.doi.org/10.6007/IJARBSS/v8-i11/4893

DOI: $10.6007 /$ IJARBSS/v8-i11/4893

Received: 11 Oct 2018, Revised: 07 Nov 2018, Accepted: 20 Nov 2018

Published Online: 24 Nov 2018

In-Text Citation: (Yusoff, Anuar, Asmuni, \& Arif, 2018)

To Cite this Article: Yusoff, H., Anuar, A., Asmuni, A., \& Arif, I. (2018). Characteristics of Effective Assatizah in Higher Religious Institutions (HRIs). International Journal of Academic Research in Business and Social Sciences, 8(11), 168-180.

\section{Copyright: (C) 2018 The Author(s)}

Published by Human Resource Management Academic Research Society (www.hrmars.com)

This article is published under the Creative Commons Attribution (CC BY 4.0) license. Anyone may reproduce, distribute, translate and create derivative works of this article (for both commercial and non-commercial purposes), subject to full attribution to the original publication and authors. The full terms of this license may be seen

at: http://creativecommons.org/licences/by/4.0/legalcode

\section{Vol. 8, No. 11, 2018, Pg. 168 - 180}

Full Terms \& Conditions of access and use can be found at http://hrmars.com/index.php/pages/detail/publication-ethics 


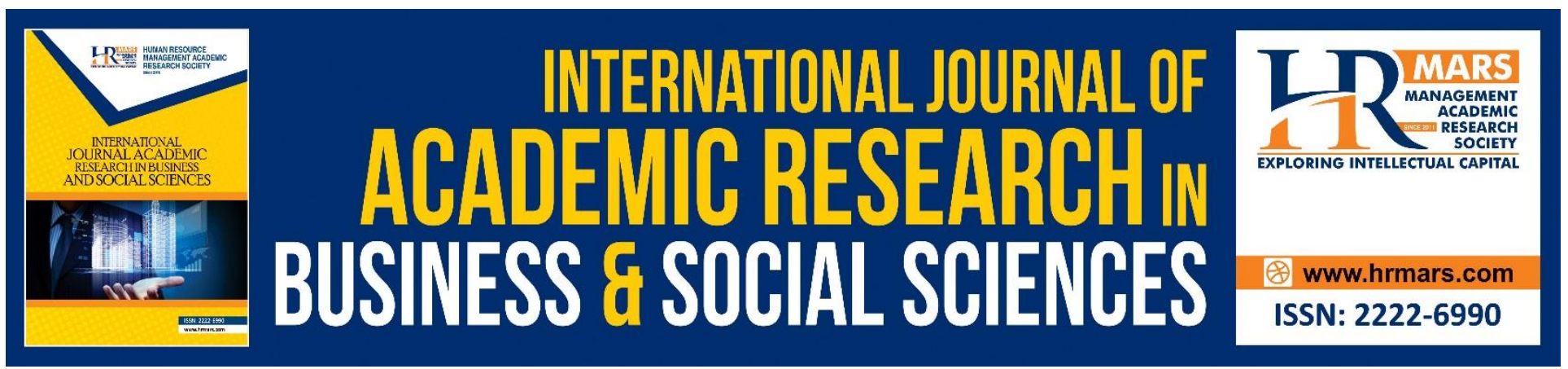

\title{
Characteristics of Effective Assatizah in Higher Religious Institutions (HRIs)
}

\author{
Husnina Yusoff \\ Universiti Putra Malaysia/ Faculty of Educational Studies, Malaysia \\ Email: husnina@upm.edu.my \\ Ashraff Anuar \\ Universiti Putra Malaysia/ Faculty of Educational Studies, Malaysia \\ Email: mohdashraff@upm.edu.my \\ Azizan Asmuni \\ Universiti Putra Malaysia/ Faculty of Educational Studies, Malaysia \\ Email: azizan@upm.edu.my \\ Ismi Arif \\ Universiti Putra Malaysia/ Faculty of Educational Studies, Malaysia \\ Email: ismiarif@upm.edu.my
}

\begin{abstract}
With the increase numbers of students registered in Tahfiz Higher Religious Institutions (HRIs) to pursue their Degree Diploma, shows that in recent years, studies in the field of Quranic are getting more encouraging response from communities. The need for professional Assatizah is so important in Islam as well among the community. Thus, it is important to study the quality of Assatizah in order to generate high qualities graduates from HRIs. Characteristics of teacher can be defined as qualities that is measurable with evaluation or their professional records. This paper is unique because the authors are investigate what qualities Assatizah need to produce high qualities graduates from HRIs. This paper highlighting specific characteristics that Assatizah need to have due to their tasks and responsibilities as an Assatizah. Assatizah must have certain specific attributes so that they can designate their role as a good Assatizah and inherit the Rasul duties. To become a professional Assatizah, they need to have knowledge, skills to teach and display positive personalities. They need to have knowledge in a) subject matters, b) knowledge in teaching; skills in a) teaching b) communication skills c) classroom management skills; affective outcomes a) self-efficacy b)
\end{abstract}


INTERNATIONAL JOURNAL OF ACADEMIC RESEARCH IN BUSINESS AND SOCIAL SCIENCES Vol. 8, No. 11, Nov, 2018, E-ISSN: 2222-6990 @ 2018 HRMARS

professionalism. A future research would discover more variables that be related in teacher characteristics in Assatizah. Another area would be teacher competencies in teaching in HRIs. Continued studies in teacher characteristic can contribute to the institute to improve job performance among Assatizah in teaching. New theories or model in job performance can open new dimension of research.

Keywords: Qualities in Assatizah, Cognitive Outcomes, Skills- Based Outcomes, Affective Outcomes, Higher Religious Institution (HRI)

\section{INTRODUCTION}

The statistics for graduates from Tahfiz HRI from year 1996 until 2017 are 2288 graduates, which 68\% are male graduates and $32 \%$ are female graduates. In 1996, there are only 18 male students and zero female student. In 2017, 136 male students and 92 female students. (Jaafar \& Tamuri, 2013). Communities started to realize the significance of sending their children into Higher Religious Institutions. In Malaysia, in recent years, studies in the field of Quranic are getting more encouraging response. (Ahmad, 2015).

In order to produce a high quality student from HRIs, Assatizah characteristics play a significant role in developing student academic achievement. There are correlation relationship in student academic achievement based on qualities of teachers. (Tygret, 2017). Past studies conducted in Malaysia proving that teacher characteristics are significant in affect academic performance and developing personalities of students. (Arbaa, Jamil, \& Razak, 2010). Teacher characteristic are responsible for $40 \%$ to $60 \%$ in average of students achievement based on assessment. (Kosgei, Mise, Odera, \& Ayugi, 2013). Characteristics of teacher can be defined as qualities that is measurable with evaluation or their professional records. (Kosgei et al., 2013). In conceptual definition, characteristics is qualities that teachers have can be measured with their professional record or assessment. When teaching in HRIs, Assatizah must have certain specific attributes so that they can designate their role as a good Assatizah and inherit the Rasul duties. To become a professional Assatizah, they need to have knowledge, skills to teach and display positive personality. (Tamuri, Khairul, \& Ajuhary, 2010).

The purpose of this literature was to identify characteristic in developing effective Assatizah in Maahad Tahfiz HRI. While there are several studies in regarding Assatizah effectiveness, further investigation needed to identify characteristics of Assatizah, particularly in higher religious education. The objective of this paper is to fill the gaps in the past literature and to understand the factors in determining qualities in effective Assatizah. The specific objectives of this paper are:

- To identify and synthesize the predictors of effective Assatizah in student academic achievement :

- Provide framework for characteristic Assatizah based on previous studies:

- Identify the theories, models and framework used in order to synthesize the predictors in various research:

\section{METHODOLOGY}

Searching published literature administered by different database such as Emerald Publishing, Science Direct, Google Scholar, Psychology and Behavioural Science Collection and reference list from key studies was applied to obtained information. In about 90 literatures were reviewed, 36 journals 
applied in this paper. Articles selected were published in between 1993 and 2017. The reference lists functions as to add support for discussion in the relevant topics by finding the title on Google search. The keywords were searched: The keywords were searched: the role of Mu'allim in institutions and communities, qualities in Assatizah, developing effective Assatizah, student academic achievement, Higher Religious Institution (HRI), scenario of graduates from HRI, multidimensional perspectives, cognitive abilities, skills based outcomes and affective outcomes. The instrument was adapted from Transfer of Training literature, from Blume, Ford and Huang (2015). The subject populations in this on-going literature are Assatizah who teaches at HRIs, their superior and also students from HRIs.

\section{Understanding Roles of Assatizah}

Assatizah derived from the word al-ismal-fa'il of 'allama which means the one who teaches. The process of teaching called al-ta'lim. (Sada, 2015). It is clear that the ta'lim process is teaching someone who does not have the knowledge by way of transferring the knowledge. (Tamuri, Khairul, \& Ajuhary, 2010). Assatizah play a significance role in unleashing human potential among institution and community. Their responsibility are not only limited as educators, but a change agents in society. (Tamuri et al., 2010).

In educating students, Assatizah is responsible developing successful students not only in the world and even in the hereafter by being a servant of ALLAH who are skilled, highly Tasawwur (Personality) in line with the teachings of Islam and thus responsible for the self, the society and the universe. (Jaafar \& Tamuri, 2013). Their responsibility not limited in life, but they develop learning afterlife. In the process of teaching and learning Islamic Assatizah are seen in society as the best example or role model potentially to change the attitude and personality of the student. \{Formatting Citation\}. They have to portray as role model because student tend impersonate their Assatizah attitudes and personalities.

As a whole, Assatizah role can be divided into seven roles 1) which are the role of preparing itself with knowledge, skills and specializations; 2) to be role model; 3) delivering syllabus with a methodology appropriate; 4) inculcate noble values to pupils; 5) creative thinking and proactive in managing Research and Development,; 6) understanding the challenges of times and environment; 7) creating conducive atmosphere when learning processes are implemented.(Jaafar \& Rashed, 2015).

One of Assatizah role is becoming a Muallim which is transmitter of knowledge. Assatizah need to teach students within the classroom to deliver their knowledge. Assatizah role is not only limited to deliver the knowledge, but Assatizah need to play a role as Muaddib, who is a trainer of akhlak and personalities by nurturing students with the knowledge of faith and noble values or ethics which been approved by Islam, so that the students can display good ethics in the society. Assatizah also need to become a murabbi (trainer of souls), need to display good role model such as have a discipline of mind, body and soul. They are also responsible in preparing students in concerted way to do their Creator's order in life (dunya) to be rewarded in the life after death (akhirah).

\section{HISTORICAL PERSPECTIVE OF HIGHER RELIGIOUS INSTITUTIONs (HRIS)}

On early $19^{\text {th }}$ century, education in Malay Archipelago was influenced by Middle Eastern modernists. (Jamsari et al., 2013). Education is important in the spread of Islam in the Malay Archipelago. 
INTERNATIONAL JOURNAL OF ACADEMIC RESEARCH IN BUSINESS AND SOCIAL SCIENCES Vol. 8, No. 11, Nov, 2018, E-ISSN: 2222-6990 @ 2018 HRMARS

(Badlihisham Mohd Nasir, 2010). Islamic education is a process of educating human mind, body and spirit based on the innate values of the Quran and al-Hadith, to generate human with Taa'wa. (Rosila, Yaacob, 2007). Islamic education is one of the ongoing efforts to apply Islamic knowledge to students and the society. (Mohd Roslan Mohd Nor \& Mohd Tarmizi Wan Othman, 2011). Islamic education important to develop taa'wa in each Muslim with the guide of Quran and Hadith. Islamic education is crucial tools for disseminate Islam knowledge in community during Malay Archipelago.

The development of Islamic education continues to grow when Land Malay achieved independence in 1957. (Zainudin Sharif \& Norazmah Mohamad Roslan, 2011). The reform of a large-scale religious education system exploded in line with the era of the rise of Islam in the early 1970s. (Badlihisham Mohd Nasir, 2010). Islamic education are vital to educate community about religion, and community aware that Islamic education are importance to bring community together as one.

The first establishment of Maahad Tahfiz in Malaysia officially begins with the by the first Prime Minister Tunku Abdul Rahman Putra Al-Haj in 1966 at Masjid Negara, Kuala Lumpur. The second maahad Tahfiz established at Kelantan in 1979 and continue to establish in every state in Malaysia. In 1980s, Terengganu, Perak, Kedah, Perlis and Selangor have established the state Maahad Tahfiz. Next at the beginning 1990s Negeri Sembilan, Malacca Pahang and Sabah have Maahad Tahfiz Negeri. And at this point

The whole country has Ma'ahad Tahfiz, the last one established in 1996, Maahad Tahfiz State of Johor and Penang. (Azmil Hashim, Tamuri, \& Jemali, 2013).

In 1984, the function of the Quran memorization Unit was expanded with became one of the departments in the Islamic Affairs Division (BAHEIS), Prime Department Minister, Kuala Lumpur. Known as Ma'had Tahfiz al-Quran wal Qiraat (MTQ). There are two objectives of setting up MTQ. First, the MTQ played a role produce Qari who hafiz al-Quran meeting the needs of the Muslim community in the country. Second, MTQ became an active center in promoting the teaching and learning of tahfiz and knowledge of the Qur'an in community. (Abdullah, Rosman, \& Faeez, 2015).

The establishment of this state tahfiz maahad has been using the Al-Quran Tahfiz Diploma program which is recognized as equivalent to UiTM Diploma by the University of Melbourne Public Service Department (PSD). The general objective of the establishment of the tahfiz institution of the Quran is to developing huffaz, qurra 'and super-skilled adolescents in line with the needs of the ummah and country. While the special objective of establishing this tahfiz institution is to produce the huffaz proficient in reading and studying al-Quran al-karim to preserve the purity and legitimacy of the Holy Qur'an al-karim and subsequently forming a cautious, knowledgeable and beneficial generation of the Qur'an to the development of the nation and the ummah. (Abdullah et al., 2015).

\section{Models of Characteristic of Teaching Multi-Dimensional Perspectives}

The model applied in this paper is Multi-dimensional learning typology which is proposed by Kraiger, Ford and Salsa in 1993. The model was proposed by extensive studies from Bloom taxanomy (1956) and Gagne (1984) taxonomies. Thus, this model consists of cognitive outcomes, skills based outcomes, affective outcomes. (Kraiger \& Ford, 1993). This model is examine three types of dimensions which a) the declarative knowledge and procedural knowledge to perform task, b) examine skills to help for better job performance, c) identifies factors which help individual for 
INTERNATIONAL JOURNAL OF ACADEMIC RESEARCH IN BUSINESS AND SOCIAL SCIENCES

Vol. 8, No. 11, Nov, 2018, E-ISSN: 2222-6990 @ 2018 HRMARS

greater self- efficacy in managing their task. This learning outcomes are associated with transfer performance. (Ford, Ford, \& Smith, 1998).

\section{Cognitive Outcomes}

In cognitive outcomes, there are verbal knowledge, knowledge organization and cognitive strategy. There are many dimension in verbal knowledge, which one of the form is declarative knowledge. (Kraiger \& Ford, 1993). Declarative knowledge is based on fact knowledge. (Aminu \& Mahmood, 2016). Declarative knowledge is real knowledge, which we are aware of it and expressed it explicitly. Declarative knowledge developed the basic of knowledge transfer. (Yilmaz, 2012). In conceptual definition, declarative knowledge is knowledge that can be obtained by reading materials due to it's based on fact information. It is knowledge that everyone have if they read about it. It can also facilitate knowledge transfer if individual tell others people about the knowledge that they have. Next, knowledge organization how individual organize their knowledge by knowing "how to do" instead "what to do" which called procedural knowledge, like for instance knowledge structure or cognitive map (Kraiger \& Ford, 1993). Knowledge organization can be good instrument to measure declarative knowledge. (Kraiger, Salas, Cannon-bowers, \& Air, 1995). Knowledge organization obtained after declarative knowledge, which mean after the individual have read the information, they know how to apply the knowledge. Lastly, cognitive strategy is known as strategic knowledge which permit individual managing their own thinking and learning process. (Lim, Yoon, Son, \& Park, 2007). Skill development are keep progressing as individual knowledge and skills continue to compile, and more task that required strategy to complete it. (Kraiger \& Ford, 1993). At this point, individual start to become independent by thinking and expand their learning process. It continue to develop their skill development as their knowledge and skill expand aligned with completing challenging work.

\section{SKILL- BASED OUTCOMES}

Skill development can be illustrated by three steps, which are a) initial skills acquisition, b) skills complication and c) skills automaticity. The initial skills acquisition translate the declarative knowledge into procedural knowledge, which enable reproduction of trained behaviour. (Kraiger \& Ford, 1993). In order to process the information, the learner can translate the information into action, which later then will reproduced trained behaviour. The compilation consists of two parts, which are proceduralization, the learners makes their performance as routine and in composition, learners applied what they have learn priorly and modified it into suitable situation. (Kraiger \& Ford, 1993). Learners make the skills to become job routine for them as proceduralization, meanwhile as composition, they used previous knowledge and adapt the knowledge into new setting of work enviroment. Automaticity enables learner to complete their task without been monitored and continue to perform in work environment. (Kraiger \& Ford, 1993). Among the three stages, these researchers categorize the skill compilation and skill automaticity stages as skill-based outcomes. (Lim et al., 2007).

\section{AFFECTIVE OUTCOMEs:}

Not only knowledge and skills are important, but also socialization agents. Learners ensure that social norms accept their choice to learn in attitudinal outcomes. (Kraiger \& Ford, 1993). They 
INTERNATIONAL JOURNAL OF ACADEMIC RESEARCH IN BUSINESS AND SOCIAL SCIENCES Vol. 8, No. 11, Nov, 2018, E-ISSN: 2222-6990 @ 2018 HRMARS

perceived supports from families and friends to pursue the learning and transfer the learning. In motivational outcomes, motivational disposition which occur in classroom can be divided into two components which are mastery or performance orientation. Mastery is individual increase their competency during hands out activities. In performance orientation, individual want to perform well and gained positive evaluation from others. (Kraiger \& Ford, 1993). Motivation dispositions can facilitate learners to do well during learning process. Individual developed their competency during hands out activities by their knowledge and skills. Another motivation can also occur when individual want recognition from others by performing well during the activities. Self- efficacy can be described as people belief in their capabilities to perform in their work. Most importantly, self- efficacy construct how people feel, think and motivation and behave. (Bandura, 1998). In self- efficacy, individual are motivated that they are capable to carry out the task with their capabilities. Selfefficacy are motivation which affecting individual feelings, think and constructing their behavior. Lastly, goal setting. Goal setting can characterize motivated behavior, direction and continuous effort of an individual. (Kraiger \& Ford, 1993). Learners also have goal orientated wants to constructing competencies by mastering difficult circumstances. There are empirical evidence that goal oriented have positive correlation of job performance. (Lunenburg, 2011). In this context, during process learning, learners have their own goal to be attained, which can constructed their behavior to be more motivated to complete the learning process.

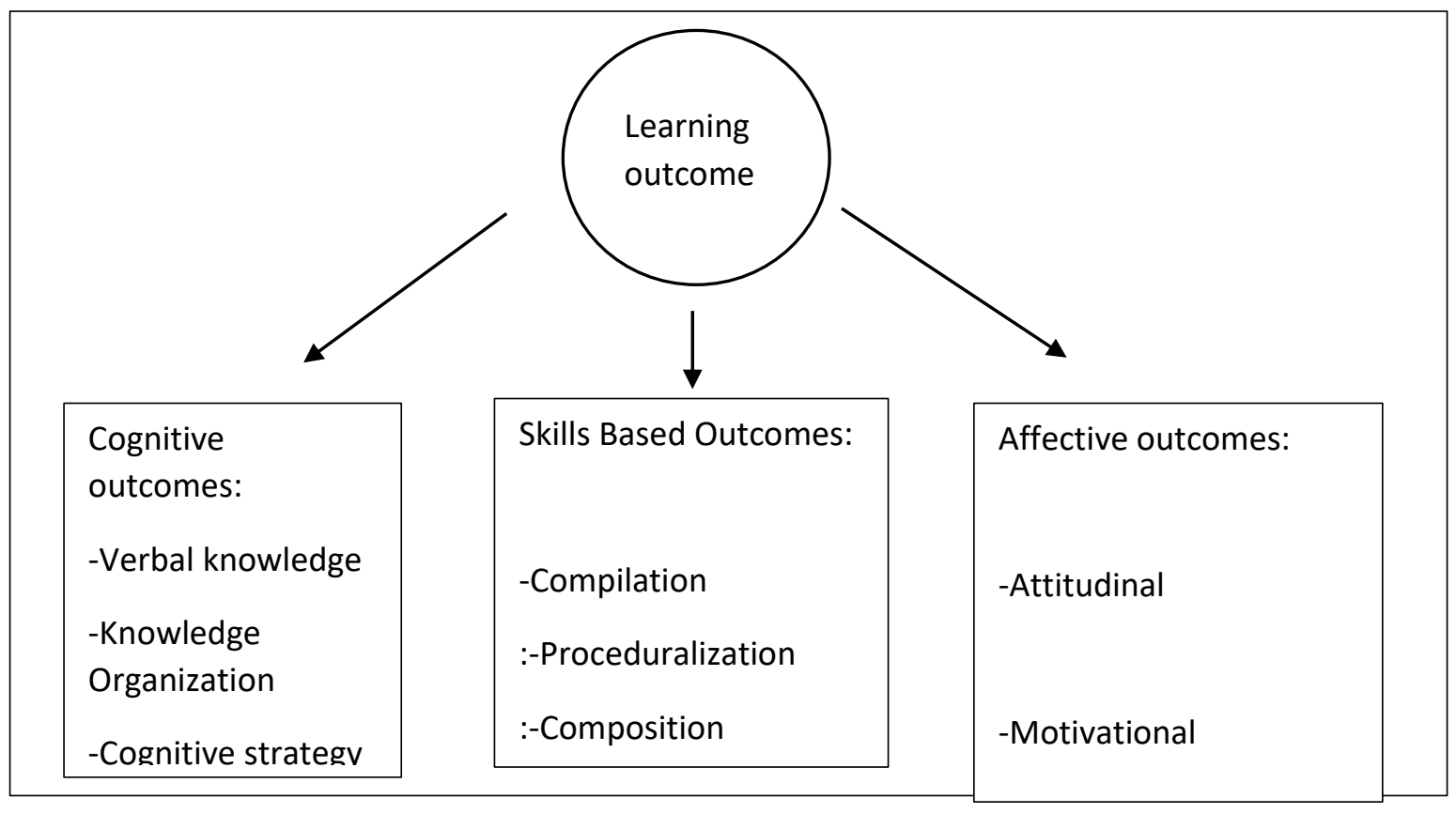

Figure 1: Learning Outcome Typology, Adopted from Kraiger, Ford \& Salsa (1993) 


\section{Cognitive Outcomes:}

\section{Declarative Knowledge in Subject Matter}

Subject matter is component of teacher knowledge. The role of teacher is to help students to learn, and provide understanding in the subject they teaches. The examples of teaching are providing explanation and examples, evaluate student understanding etc. (Ball \& McDiarmid, 1990). Deep understanding subject matter is crucial components for Assatizah. As Assatizah, they need to become knowledgeable individual in carrying out their duties and their role because the task of conveying knowledge is the trust of God. (Tamuri et al., 2010). Subject matter in Quran such as "talaqqi" (Mu'allim give example of the Quran reading and the student follow the reading accordingly) and "musyafahah" (students receive teaching in the form of teachers by looking at the movements teacher's lips and call it). (Sedek, 2007). Assatizah have huge responsibility in developing human potential among their students. Assatizah need to have depth understanding Quran learning, in order to be knowledgeable and able to deliver knowledge in their expertise field.

\section{DECLARATIVE KNOWLEDGE IN TEACHING}

Each Assatizah need to have knowledge in teaching. Having knowledge in subject expertise and audiences is not adequate. Assatizah need to have knowledge in teaching for educating Huffaz. The right approaches like for example, in term of approach and methodology, Assatizah need to use the appropriate techniques required to stimulate students' interest during the teaching and learning process. (Tamuri et al., 2010). There are four types of knowledge in teaching that been implement by most HRIs such as a) talqin (teaching), b) takrar (continuous practise), c) al-mail (love al-Quran) and d) al-fahm (understanding). Mu'allim need to have knowledge in teaching in order to facilitate learning among students.

\section{SKILLS- BASED OUTCOMES: TEACHING SKILLS}

Teaching skills or teaching skills include planning, management, presentation, guidance and assessment activities with the aim of effectively disseminating knowledge or skills to pupils, using approaches, strategies, methods and teaching techniques based on teaching and learning theories. Teaching skills will enable teaching activities to be systematically, step by step, ie from the beginning of the stage followed by the conceptualization stage through the use of knowledge and skills and end with reinforcement and consolidation activities. (Tamuri et al., 2010). As a result, Assatizah will be able to motivate the students and draw their attention to be willing to follow the lesson with interest. (Tamuri et al., 2012). For instance, Assatizah need to have teach Quran knowledge such as "talaqqi," as for example at first, then proceed to takrar which is continuous practice in memorizing Quran. Assatizah also need to implement methods to make students fall in love reading and memorizing Quran. Students also need to understand Quran which help the process of memorizing it. \{Formatting Citation\}.

\section{Communication Skills}

As Assatizah, they need to have communication skills. In order to generate high qualities graduates, communication during learning session should be two way communication. Teachers should work 
improving their relationship with students inside classroom. The task of the teacher is not simply to convey knowledge but ensures knowledge is received and understood by his students. This will only happen when teachers care about academic development their students. Teachers need to be ready to talk with every student to identify his or her strength and their weaknesses. (Arbaa et al., 2010). Teaching skills such as Assatizah uses an easy language barrier will facilitate students understanding in explanation in term of value of the Quran. The language used should be easy to understand and close to the student daily life. (Nabiroh Kassim, Nik Mohd Rahimi Nik Yusof, 2014). Interactive discussions between teachers and students makes the classroom more lively. Without good activities and communication between students and teachers, effective teaching is difficult generated. This finding shows that the two-way communication factor between teacher and student is very much important in the teaching and learning process. (Yusof, 2014).

\section{Classroom Management Skills}

Classroom management is crucial taking aspect of student's needs, preparing techniques and activities, assessment, and evaluation criteria. Teacher need to provide clear instruction in order to facilitate student motivations and passion during learning session. (Moreno Rubio, 2009). Examples of classroom in HRIs are Nazirah and Tahfiz classroom. The lesson to be taught in addition to the Nazirah classroom is Qur'anic lessons such as Fardhu ain, Tajwid, Morals and Jawi Lessons. In Tahfiz classroom, Students will usually end up learning tahfiz after 3 to 5 years (2 year for Sabaq and 2 years for Daur). Each student is required at least memorizing 8 to 10 Juzuk a year. Before khatam sabaq 30 juzuk, students is required to memorize smoothly for 15 Juzuk only to be permitted sabaq. After graduating from 30 Juzuk, students will establish their memorization for 6 to 2 years until completing the final examination. This learning classroom was illustrated from of Studies in Madrastul Quran Kubang Bujuk, Kelantan. (Hashim, 2012). Assatizah need to have classroom management skills so that learning lesson would be interesting for both parties. Assatizah need to able having control in their classroom to smoothen learning session. In Nazirah class, Assatizah need capture students' interest during learning session. In Tahfiz class, Assatizah need to use different approaches and techniques because it depend on level of memorization of Quran. Assatizah need to have skills in classroom management because different subject, different need of student approaches. This is why classroom management skills are important.

\section{Affective Outcomes \\ Self- Efficacy}

Teachers' confidence are important tool to developed effective teacher. A teacher should be confident to teach students, and thus can influences teaching outcome. (Moreno Rubio, 2009). Selfefficacy are important to Assatizah because it facilitate teacher's role to guide and gave education, which requires resilient, patient and creativity. Assatizah who have high self- efficacy will always have a positive regarding the students and they tend to put high expectations for success of their students. (Jaafar, Halim, Asiah, \& Muhamad, 2012). Self- efficacy are can be conceptualized as teacher motivation in performing their duties as Mu'allim, which requires positive attitudes. It can facilitate learning because Assatizah have the capability in performing their job. They have high self- efficacy in developing students because they want to ensure that their students success in life and afterlife. 
INTERNATIONAL JOURNAL OF ACADEMIC RESEARCH IN BUSINESS AND SOCIAL SCIENCES Vol. 8, No. 11, Nov, 2018, E-ISSN: 2222-6990 @ 2018 HRMARS

\section{Professionalism}

There are three features of professionalism in teacher a) have content knowledge $b$ ) having skills and skills in the teaching process $\mathrm{c}$ ) become role model to the students. (Abdull \& khuan wai, 2014). There is still lacking professionalism among Assatizah in HRIs. Assatizah need to have adequate knowledge, skills to teach and becoming role model to the students. In the context of teaching and learning, the noble personality inherent in the teacher itself plays a very important role in forming good values in the student. Assatizah need to emulate the character of the Prophet s.a.w. as a "role model" in all aspects of life. (Amin, Zainal, \& Mustari, 2012). Spiritual qualities such as sincere, honest, patience, warak and taqwa can be achieved when Mu'allim are dedicated to his duty. (Jasmi \& Tamuri, 2012).

\section{Qualities of Teachers}

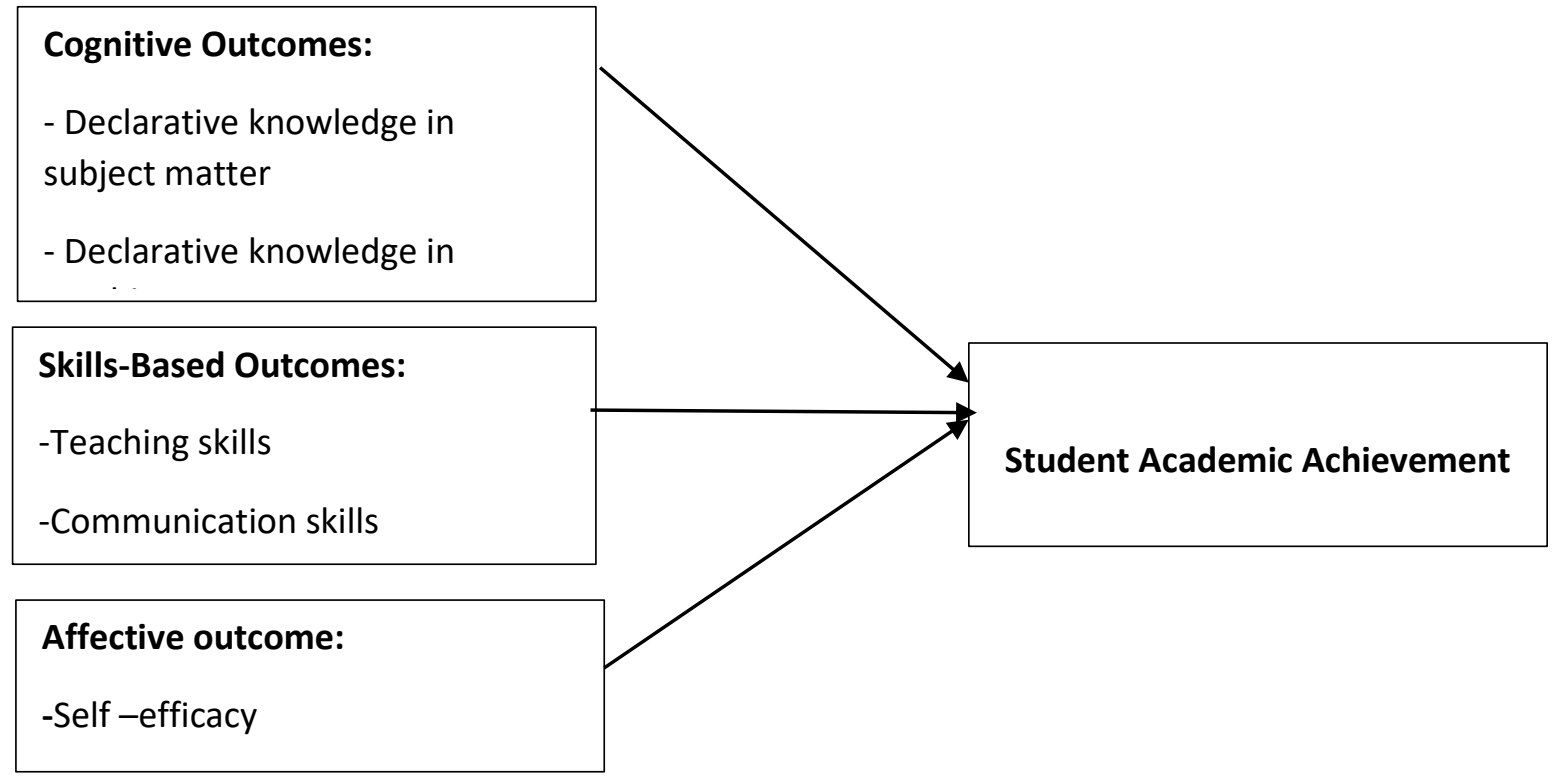

Figure 2: Transfer of Training, Adapted from Blume, Ford and Huang (2015)

In term of practical significance, the findings of this study will facilitate religious institutions educator to become professional educators. This study can serve as a guide for Dasar Pendidikan Tahfiz Negara (DPTN) to increase teacher competency in order to empower Tahfiz Instutions. Hence, this study can contribute toward understanding individual behaviour during performing their work. This study intended to propose a standard of measurement to measure religious teacher behavior in organization. This standard of measurement is important because JAKIM want to develop identity and show identity as driving force of religious institution in Malaysia. (Ahmad, 2015) as aligned with DPTN which to improve teacher competency among Tahfiz educators. In term of theoretical, this literature will contribute in the field of Human Resource Development (HRD), especially religious teacher who transfer their knowledge and skills to the students in Quran learning. This study is 
INTERNATIONAL JOURNAL OF ACADEMIC RESEARCH IN BUSINESS AND SOCIAL SCIENCES

Vol. 8, No. 11, Nov, 2018, E-ISSN: 2222-6990 @ 2018 HRMARS

important to serve as a basic policy for improvement and career development of religious teacher as well as guidelines in performance measurement in HRD field.

\section{Conclusion and Recommended (motivation)}

As been discussed in the paper, lacking of Assatizah in society, not just affecting institution and community, but also development of country. This paper intended to fill the gaps in the past literature and to understand the characteristic of Mu'allim influencing student academic achievement in HRIs. Teachers characteristic can be defined as teacher qualities which can be measure by his or her background education or individual assessment evaluation. Several literature identifies factors in teacher characteristic can lead to student performance. A future research would discover more variables that be related in teacher characteristics. Another area would be teacher competencies in teaching in HRIs. Continued studies in teacher characteristic can contribute to the institute to improve performance among Assatizah in teaching. The authors suggested that an Assatizah should portray Rasulullah duties as teacher such as roles in mualim. Therefore, there is a need to explore more on how what are features of Rasulullah in becoming a teacher, and what can facilitate teacher inherit Rasulullah duties. New theories or model in job performance can open new dimension of research.

\section{REFERENCES}

Abdull, O., \& Khuan, W. (2014). PERKEMBANGAN PROFESIONAL GURU SECARA BERTERUSAN : PERSPEKTIF PEMBANGUNAN SUMBER. MYJUrnal, 28(1), 131-141

Abdullah, M., Rosman, S., \& Faeez, I. (2015). PENDIDIKAN TAHFIZ DI MALAYSIA : SATU SOROTAN SEJARAH. Paper presented at the International Conference on Islamic Education and Social Entrepreneurship, Langkawi, Malaysia.

Ahmad, N. (2015). MEMPERKASA DARUL QURAN KE ARAH MEMARTABAT PENDIDIKAN TAHFIZ DI MALAYSIA. Paper presented at the $5^{\text {th }}$ Simposium Pendidikan Tahfiz Nusantara Dan Multaqa Huffaz, Bandar Baru Bangi, Malaysia.

Ahmad, S. S., Sarina, T., \& Tengku, A. (2017). PERMASALAHAN DAN CABARAN GURU PENDIDIKAN ISLAM ( GPI ) DALAM MEMBENTUK PERSONALITI DAN AKHLAK PELAJAR : SATU ANALISIS SECARA $K R I T I S$. Paper presented at the International conference on islam, development and social harmony, Bandar Baru Bangi, Malaysia.

Aminu, I., \& Mahmood, R. (2016). On the Relationship Between Procedural and Declarative Organization Memory and their Effects on SME Performance. International Business Management, 10(3), 241-247.

Arbaa, R., Jamil, H., \& Razak, N. abd. (2010). Hubungan Guru-Pelajar dan Kaitannya dengan Komitmen Belajar Pelajar: Adakah Guru Berkualiti Menghasilkan Perbezaan Pembelajaran antara Jantina Pelajar? Jurnal Pendidikan Malaysia, 35(2), 61-69.

Badlihisham Mohd Nasir. (2010). Pendidikan dalam Gerakan Islam di Malaysia : Satu Tinjauan. Journal of Islamic and Arabic Education, 2(1), 1-12.

Ball, D. L., \& McDiarmid, G. W. (1990). The subject matter preparation of teachers. Handbook of Research on Teacher Education, 437-449.

Bandura, A. (1998). Health promotion from the perspective of social cognitive theory. Psychology and 
INTERNATIONAL JOURNAL OF ACADEMIC RESEARCH IN BUSINESS AND SOCIAL SCIENCES

Vol. 8, No. 11, Nov, 2018, E-ISSN: 2222-6990 @ 2018 HRMARS

Health, 13, 623-649.

Hashim, A., Tamuri, A. H., \& Jemali, M. (2013). Latar Belakang Guru Tahfiz Dan Amalan Kaedah, 1(1), 28-39.

Jaafar, N., Halim, A., Asiah, N., \& Muhamad, F. (2012). The Importance of Self-Efficacy : A Need For Islamic Teachers as Murabbi. Procedia-Social and Behavioral Sciences, 69(Iceepsy), 359-366. https://doi.org/10.1016/j.sbspro.2012.11.421

Jaafar, N., \& Rashed, Z. N. (2015). MODEL KUALITI GURU PENDIDIKAN ISLAM SEBAGAI MURABBI, 1(1), 101-108.

Jaafar, N., \& Tamuri, A. H. (2013). Hubungan Antara Efikasi Kendiri Dengan Kualiti Guru Pendidikan Islam Sekolah Menengah Kebangsaan Malaysia, 5(1), 41-60.

Jamsari, E. A., Sulaiman, A., Umar, A., Civilization, I., Sains, U., \& Sembilan, N. (2013). Religious Education in Malaya-Malaysia : A Lesson from the Indian Modernization, 7(10), 500-506.

Jasmi, K., \& Tamuri, H. (2012). Komponen Asas untuk Latihan Guru Pendidikan Islam. Global Journal Al-Thaqafah, 2(2), 53-63

Kosgei, A., Mise, J. K., Odera, O., \& Ayugi, M. E. (2013). Influence of teacher characteristics on students ' academic achievement among secondary schools. Journal of Education and Practice, $4(3), 76-82$.

Kraiger, K., Ford, J.K. and Salas, E. (1993) Application of Cognitive, Skill-Based, and Affective Theories of Learning Outcomes to New Methods of Training Evaluation. Journal of Applied Psychology, 78, 311-328

Kraiger, K., Salas, E., Cannon-bowers, J. A., \& Air, N. (1995). Measuring Knowledge Organization as a Method for Assessing Learning during Training, Journal of Human Factors, 37(4), 804-816.

Lim, D. H., Yoon, S. W., Son, S. J., \& Park, S. (2007). Typology of Learning Outcomes in Cognitive Domain: What Is Said vs. What Is Measured. Paper presented at the International Research Conference in the Americas of the Academy of Human Resource Development, Indianapolis.

Lunenburg, F. C. (2011). Goal-Setting Theory of Motivation, International journal of management, business, and administration, 15(1), 1-6.

Marzuqi, M., Rahim, A., \& Hashim, A. (2017). Pendekatan Pengajaran dalam Kalangan Pensyarah Tahfiz Al-Quran di Malaysia Teaching Approaches among the Tahfiz Al-Quran Lecturer in Malaysia, Jurnal Perspektif: Special Issue, 1(1), 79-88.

Nor, M. R. M. \& Othman, M. T. W. (2011). Sejarah dan Perkembangan Pendidikan Islam di Malaysia. Jurnal At-Ta'dib, 6(1), 59-78.

Moreno Rubio, C. (2009). Efective teachers-profesional and personal skills. ENSAYOS, Revista.

Nabiroh Kassim, Nik Mohd Rahimi Nik Yusof, A. H. T. (2014). Kepercayaan Guru Pemangkin Amalan Penerapan Nilai Murni dalam Pengajaran Tilawah al-Quran. Juornal of Al-Quran \& Tarbiyyah, 1(1), 33-42.

Ramlie, A., Hussin, Z., Saedah, S., \& Ridhuan, M. J. M. (2016). KEPERLUAN PROFESIONALISME GURU PENDIDIKAN ISLAM (GPI) DALAM ASPEK PENGAJARAN, e-Jurnal Penyelidikan dan Inovasi, 3(3), 85-109. http://rmc.kuis.edu.my/jpi/wp-content/uploads/2016/09/HABIBAH-85-109-1.pdf

Rosila, N., Yaacob, N., Pengajian, P., \& Pendidikan, I. (2007). Penguasaan Jawi Dan Hubungannya Dengan Minat. Pendidik Dan Pendidikan, Jil. 22, 161-172.

Sedek, A. (2007). Kepentingan Talaqqi Dan Musyafahah Dalam Pembacaan Al-Quran, 1-10. Retrieved 
INTERNATIONAL JOURNAL OF ACADEMIC RESEARCH IN BUSINESS AND SOCIAL SCIENCES

Vol. 8, No. 11, Nov, 2018, E-ISSN: 2222-6990 @ 2018 HRMARS

from

http://repository.um.edu.my/87964/1/Kepentingan\%20Talaqqi\%20Musyafahah\%20Untuk\%20 Jurnal\%20DQ.pdf

Tamuri, A. B. H., Khairul, M., \& Ajuhary, A. (2010). Amalan Pengajaran Guru Pendidikan Islam Berkesan Berteraskan Konsep Mu ' allim, Journal of Islamic and arabic education ,2(1),43-56.

Tygret, J. A. (2017). The influence of student teachers on student achievement : A case study of teacher perspectives. Teaching and Teacher Education, 66, 117-126.

Yilmaz, i. (2012). The Relationship of Procedural and Declarative Knowledge of Science Teacher Candidates in Newton's Laws of Motion to Understanding, American International Journal of Contemporary Research, 2(3), 50-56.

Rahim, A, M., Yussuf, A., Borham, A, B., Zaman, M,A,K. (2016). Journal of Islamic Educational Research (JIER),Special Issue, 1(1), 1-10

Zainal, N,A, S., \& Mustari, M. I. (2012). Penerapan Metode Dakwah Di Dalam Melaksanakan Proses Pengajaran Dan Pembelajaran (P\&P) Di Dalam Dan Luar Bilik Darjah. Paper presented at the International Seminar on Teacher and Islamic Education, Johor, Malaysia.

Sharif, Z. \& Roslan, M.M. (2011). Faktor-Faktor Yang Mempengaruhi Remaja Terlibat Dalam Masalah Sosial Di Sekolah Tunas Bakti, Sungai Lereh, Melaka. Journal of Education Psychology \& Counseling, 1, 115-140. 